Jurnal Konstruksi Hukum | ISSN: 2746-5055

Vol. 2, No. 2, Mei 2021 Hal. 320-325| Tersedia online di

https://www.ejournal.warmadewa.ac.id/index.php/jukonhum

DOI: https://doi.org/10.22225/jkh.2.2.3230.320-325

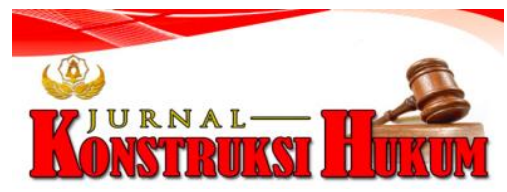

\title{
PERJANJIAN PINJAMAN ONLINE BERBASIS FINANCIAL TECHNOLOGY (FINTECH)
}

\author{
Ni Made Eka Pradnyawati, I Nyoman Sukandia, Desak Gde Dwi Arini \\ Fakultas Hukum Universitas Warmadewa, Denpasar-Bali, Indonesia \\ ekapradnya04@gmail.com, nyomansukandia@gmail.com, arinidesak1966@gmail.com
}

\begin{abstract}
Abstrak
Financial Technology (Fintech) merupakan salah satu altenatif teknologi yang memudahkan transaksi pinjaman yang bisa dilakukan secara online. Pinjaman online menimbulkan masalah baru seperti maraknya penipuan dan terjadinya wanprestasi. Mengacu pada masalah yang telah diuraikan, penelitian ini dilakukan dengan tujuan menjelaskan kedudukan hukum perjanjian pinjaman online berbasis financial technology (Fintechl), dan mengetahui perlindungan hukum terhadap kreditur yang memberikan pinjaman online berbasis Financial Technology (Fintech). Penelitian ini menggunakan penelitian hukum normatif. Sumber data yaitu bahan hukum primer dan sekunder, data dikumplkan dengan teknik pencatatan dalam perolehan bahan hukum secara primer dan sekunder yaitu menelaah beberapa bahan bacaan seperti jurnal-jurnal, buku-buku ilmiah dan peraturan perundang-undangan. Setelah data terkumpul, selanjutnya dianalisis secara kualitatif. Hasil penelitian menunjukkan bahwa kedudukan hukum perjanjian pinjaman online berbasis financial technology (Fintech) apabila ditinjau secara hukum maka perjanjian online sah secara hukum karena memiliki landasan yaitu Pasal 1320 KUH Perdata dan keabsahan bukti-bukti yang digunakan mengacu pada undang-undang Nomor 11 Tahun 2008 tentang Undang-Undang ITE Pasal 5 tentang informasi, dokumen dan tanda tangan elektronik. Perlindungan hukum terhadap kreditur dalam perjanjian pinjaman online berbasis financial technology (Fintech) terdiri atas perlindungan hukum preventif dan perlindungan hukum represif.
\end{abstract}

Kata Kunci: Financial Technology (Fintech), Perjanjian, Pinjaman Online.

\begin{abstract}
Financial Technology (Fintech) is a technology alternative that facilitates loan transactions that can be done online. Online loans create new problems such as rampant fraud and default. Referring to the problems described, this research was conducted with the aim of explaining the legal position of financial technologybased online loan agreements (Fintechl), and knowing the legal protection of creditors who provide financial technology-based online loans (Fintech). This research used normative legal research. Sources of data are primary and secondary legal materials, data are combined with recording techniques in obtaining primary and secondary legal materials, namely examining several reading materials such as journals, scientific books and statutory regulations. After the data is collected, it is then analyzed qualitatively. The result showed that the legal position of online loan agreements based on financial technology (Fintech) when reviewed legally, the online agreement is legally valid because it has a basis, namely Article 1320 of the Civil Code and the validity of the evidence used refers to law Number 11 of 2008 concerning Article 5 of the ITE Law on information, documents and electronic signatures. Legal protection for creditors in an online loan agreement based on financial technology (Fintech) consists of preventive legal protection and repressive legal protection.
\end{abstract}

Keywords: Financial Technology (Fintech), Agreement, Online Loans.

\section{PENDAHULUAN}

Peran teknologi dalam beberapa dekade terakhir ini berkembang sangat pesat. Teknologi masuk ke berbagai sistem kehidupan manusia mulai dari ekonomi, pendidikan, keamanan dan politik. Penerapan teknologi pada berbagai bidang tidak lain bertujuan untuk meningkatkan efisiensi terhadap usaha yang dikeluarkan manusia dengan tetap menghasilkan hasil yang sesuai dengan tujuan yang diinginkan (Wahyuni \& Turisno, 2019). Kemudahan dalam berbagai hal yang ditawarkan teknologi membuat semua pihak tergiur untuk berlomba-lomba menerapkan sistem berbasis teknologi yang paling canggih dan terbaru. Jadi pemanfaatan teknologi didukung seluas-luasnya semasih dalam rangka mensejahterakan masyarakat (Noor, 2011).

Salah satu sektor yang diterjang derasnya arus kemajuan teknologi adalah sektor perekonomian. Contoh yang termasuk penerapan teknologi dalam perekonomian adalah adanya e- 
banking dan e-commerce. Peran dari teknologi tersebut untuk memudahkan proses transaksi keuangan tanpa interaksi secara fisik dan menggunakan waktu yang lama. Seseorang yang ingin melakukan sebuah transaksi tidak perlu datang ke bank, melainkan bisa dilakukan melalui aplikasi e-banking yang bisa diunduh pada smartphone yang digunakan. Apabila seseorang ingin berbelanja tidak harus datang ke toko atau lokasi pembelian, melainkan bisa memesannya melalui e-commerce yang juga berupa sebuah layanan aplikasi. Hal tersebut menunjukkan bahwa pemanfaatan teknologi dalam bidang perekonomian memiliki dampak yang signifikan untuk peningkatan pertumbuhan ekonomi suatu Negara (Yuliana, 2000).

Kebutuhan akan modal usaha merupakan hal yang wajib, dewasa ini untuk membangun usaha, khususnya adalah UMKM. Kemudahan dalam memperoleh modal usaha akan mempercepat perkembangan UMKM sehingga roda perekonomian bisa berputar. Peran UMKM dalam perekonomian di Indonesia cukup besar karena memiliki jumlah sekitar 64,2 Juta unit, dengan penyerapan $97 \%$ dari keseluruhan tenaga kerjanya. Melihat potensi ini yang cukup besar, maka banyak pihak yang melihat peluang pinjaman untuk modal usaha cukup tinggi. Oleh karenanya berbagai pihak berlomba untuk menawarkan kemudahan dalam proses pengajuan dan pencairan dana pinjaman.

Financial Technology ( Fintech) merupakan salah satu alternatif teknologi yang memudahkan transaksi pinjaman yang bisa dilakukan secara online. Praktik bisnis pinjarnan online tersebut berbasis Peer to peer lending (P2PL), sistem ini memfasilitasi hubungan pihak yang akan memberi pinjaman (debitur) kepada pihak peminjam yang terjadi secara online (Baihaqi, 2018). Tercatat selama Tahun 2019 sebanyak Rp. 22 Triliun kredit tersalur melalui sistem pinjaman online tersebut (Budiyanti, 2019). Berdasarkan fakta tersebut maka sistem pinjaman online punya peminat yang bisa dibilang cukup tinggi di sebuah kalangan masyarakat. Pinjaman online memberi kemudahan pihak pemberi pinjaman dan peminjam melakukan transaksi yang bisa dilakukan dimana saja. Terbukti dari data OJK per 5 Agustus 2020 terdapat 158 perusahaan fintech yang tercatat secara resmi di Indonesia seperti PT. Danamas, PT. Amartha, PT. Toko Modal, PT. Pohon Dana di Negara Indonesia (Pohondana), dan masih banyak lagi perusahaan yang telah terdaftar.

Keberadaan aplikasi pinjaman secara online berbasis Peer to peer lending sah secara hukum yang diatur melalui POJK o.77/POJK.01/2016 tentang Layanan Pinjaman sebuah uang yang berbasis pada bidang teknologi lnfonnasi. Meskipun sudah memiliki regulasi, namun masih ada kekosongan hukum pada peraturan tersebut. Kekosongan hukum tersebut diberikan manfaat oleh pihak yang ingin mendapat sebuah keuntungan yang lebih banyak dengan memakai cara yang tidak sesuai. Pada kasus pinjaman online, pemenuhan keempat syarat sah suatu perjanjian sesuai KUH Perdata pada dasarnya sama dengan perjanjian konvensional. Akan tetapi dalam hal pembuktian akan lebih sulit karena pihak yang berikatan melakukan perjanjian tanpa melalui interaksi langsung. Permasalahan yang timbul bisa terjadi karena debitur yang melakukan cidera janji atau kredirur yang melakukan penagihan dengan cara yang tidak manusiawi (Sugangga \& Sentoso, 2020). Terbukti dari data pengaduan yang diterima oleh YLKI yang mencatat jika terdapat 39,5\% keluhan berkaitan dengan cara penagihan utang yang dilakukan oleh pihak pemberi pinjaman tidak sesuai dengan aturan, salah satunya yaitu menggunakan pihak ketiga sebagai debit collector. Oleh karenanya perlindungan secara hukum terhadap pihak peminjam diperlukan untuk mengantisipasi apabila terjadi pelanggaran hukum dalam proses penagihan utang pinjaman online.

Ada beberapa penelitian terdahulu terkait penelitian ini yaitu (Istiqamah, 2019a); (Novinna, 2020); dan (Fais, 2021) mengungkapkan bahwa perbuatan hukum yang timbul antara debitur dengan kreditur dalam proses pinjaman secara online harus berdasarkan perjanjian, hal ini diikat dengan kedudukan hukum selaku debit collector dengan pihak penyelenggara pinjaman online P2P Lending adalah sebagai pihak ketiga dalam hubungan kerja sama yang dimana tiap pihak memiliki kewajiban masing-masing, selanjutnya pengguna layanan produk pembiayaan khususnya bagi pemberi pinjaman harus diberi perlindungan hukum sesuai peraturan otoritas jasa keuangan nomor 7/pojk.01/2016 tentang pinjam meminjam uang berbasis teknologi informasi. Berdsarkan dari beberapa penelitian terdahulu, maka dalam penelitian ini mencoba melakukan penelitian dengan proses pengajian yang berbeda dengan tujuan menjeaskan kedudukan hukum perjanjian pinjaman online berbasis Financial Technology (Fintechl) dan mengetahui perlindungan hukum terhadap kreditur yang memberikan pinjaman online berbasis Financial Technology (Fintech) 


\section{METODE PENELITIAN}

Penelitian ini didesain dengan penelitian hukum normatif, yaitu penelitian yang melakukan kajian pada peraturan hukum yang memakai literatur menjadi konsep, teori serta pendapat dari ahli hukum pada permasalahan yang selanjutnya akan dianalisis. Sumber data yang digunakan yaitu bahan hukum primer, bahan hukum sekunder, serta bahan hukum tersier. Data diperoleh dengan cara studi pencatatan dalam perolehan bahan hukum secara primer serta bahan hukum secara sekunder yaitu dengan menelaah beberapa bahan bacaan seperti jurnal-jurnal, buku-buku ilmiah dan peraturan perundang-undangan. Analisis bahan hukum yang didapat melalui sebuah sumber yang dikumpulkan, diklasifikasi, kemudian dianalisis secara kualitatif (Sugiyono, 2013)

\section{HASIL DAN PEMBAHASAN}

\section{Kedudukan Hukum Perjanjian Pinjaman Online Berbasis Financial Technology (Fintech)}

Berkaitan dengan pinjaman online, pinjaman yang dilaksanakan melalui perantara media online atau daring. Pinjaman online yaitu sebuah fasilitas dalam pinjaman uang kepada penyedia jasa pada bidang keuangan yang dioperasikan secara online. Jadi perjanjian pinjaman online adalah sebuah jenis perjanjian pinjaman biasa akan tetapi yang membedakan yaitu media perantaranya melalui media daring atau online. Dalam pelaksanaan perjanjian pinjaman online antara debitur dan kreditur tidak membutuhkan ruang untuk berinteraksi secara langsung. Namun interaksi tersebut bisa dilakukan dengan menggunakan perangkat elektronik (Istiqamah, 2019b).

Perjanjian pinjaman online berbasis Financial Technology (Fintech) di Indonesia memiliki dasar hukum yaitu Peraturan Otoritas Jasa Keuangan. Akan tetapi belum ada aturan undang-undang yang mengatur tentang mekanisme dan keabsahan perjanjian pinjaman online berbasis Financial Technology (Fintech). Bermodalkan peraturan tersebut pelaksanaan perjanjian sudah dikatakan sah secara hukum, akan tetapi karena sifat peraturan tersebut hanya mengatur mekanisme, sedangkan pelanggaran dan wanprestasi dari pihak yang melakukan perjanjian akan sulit untuk ditindak lanjuti secara hukum karena belum ada payung hukum yang mengatur mengenai sanksi terhadap pihak yang melakukan pelanggaran.

Terdapat empat syarat yang menjadi syarat subjektif dan objektif dari suatu perjanjian yaitu syarat subjektif meliputi kesepakatan yang saling terhubung, kecakapan dalam menciptakan sebuah ikatan. Selanjutnya syarat objektif dari perjanjian adalah sebuah hal tertentu dan sebuah penyebab yang secara halal. Suatu perjanjian dikatakan memiliki keabsahan secara hukum apabila syarat subjektif dan objektif seperti yang disebutkan tersebut terpenuhi oleh kedua pihak yang menciptakan perjanjiannya.

Apabila terjadi pelanggaran atau tidak dipenuhinya syarat-syarat perjanjian tersebut maka akan menimbulkan akibat hukum. Jika pada syarat subjektifnya belum terpenuhi, maka perjanjiannya mampu dibatalkan. Ketentuan hukum yang mengatur perjanjian melalui internet atau online sama dengan ketentuan hukum yang mengatur mengenai perjanjian langsung atau konvensional. Pernyataan tersebut bermakna bahwa perjanjian online tunduk terhadap ketentuan perjanjian langsung atau konvensional. Karena pada dasarnya isi dan mekanisme perjanjian tidak berbeda, akan tetapi yang rnembedakan antara keduanya hanya media yang digunakan, sehingga antara perjanjian online dan perjanjian langsung atau konvensional memiliki dampak hukum yang sama (Ghazali \& Usman, 2012).

Perjanjian pada umumnya atau perjanjian konvensional dipersepsikan sebagai perjanjian yang dilaksanakan dengan bukti berupa surat perjanjian yang berbentuk sebuah kertas yang ditandatangani kepada kedua belah pihak yang sedang berjanji. Adapun syarat dan ketentuan sahnya suatu perjanjian mengacu pada Pasal 1320 KUH Perdata, yang mana pada ketentuan pasal tersebut menyebutkan terdapat empat syarat sahnya suatu perjanjian konvensional yaitu terdapat kesepakatan, dilakukan oleh subjek hukum yang cakap, terdapat suatu sebab tertentu, dan tidak boleh bertentangan dengan Undang-Undang. Perjanjian pada umumnya atau yang konvensional memerlukan pertemuan antara kedua belah pihak atau melalui perantara. Karena dalam penandatanganan wajib untuk dilakukan secara langsung. Hal ini yang menjadi kekurangan dari perjanjian konvensional karena membutuhkan waktu yang lebih lama. Melalui ketersediaan teknologi informasi maka pelaksanaan perjanjian tersebut bisa dilakukan dengan fasilitas media elektronik, namun dengan menggunakan syarat keabsahan dan bukti perjanjian yang sama dengan perjanjian pada umumnya. 
Faktor yang mernbedakan antara perjanjian pinjaman secara konvensional dan perjanjian pinjaman online hanya dalam sebuah media yang dipakai, jika dalam perjanjian konvensional seorang pihak yang seharusnya terlihat secara langsung pada sebuah tempat untuk melakukan kesepakatan tentang apa yang akan diperjanjikan serta bagaimana mekanisme pengembaliannya dan menandatangani surat perjanjian sebagai bukri fisik. Sedangkan dalam perjanjian pinjaman online, proses perjanjian yang dilaksanakan melalui media online. Sehingga proses pelaksanaan perjanjian akan bisa dijalankan tanpa adanya sebuah pertemuan yang secara langsung dari pihak yang terkait. Sebuah dokumen elektronik selayaknya dinyatakan sah apabila dibubuhi tanda tangan oleh pihak terkait. Tanda tangan yang digunakan dalam perjanjian elektronik juga berupa tanda tangan elektronik, dan dinyatakan sah secara hukum apabila memenuhi persyaratan berdasarkan Pasal 11 Undan- Undang ITE.

Dalam pelaksanaannya, perjanjian pinjaman secara online tidak mempertemukan pihak yang melaksana kan perjanjian, akan tetapi pihak dari pemberi pinjaman dan penerima pinjaman dihubungkan oleh penyelenggara pinjaman secara online. Jadi bukti-bukti dan jaminan yang digunakan diberikan secara elektronik. Berdasarkan hal tersebut maka potensi dari perjanjian pinjaman secara online merniliki peluang risiko yang lebih besar untuk menimbulkan masalah sengketa. Diketahui bahwa perjanjian melalui media online berisiko lebih tinggi daripada perjanjian secara konvensional. Terdapat sanksi yang diberikan terhadap pihak-pihak yang melakukan wanprestasi terhadap perjanjian yang melakukan kesepakatan. Oleh karenanya kedua belah pihak yang terlibat dalam perjanjiannya wajib untuk menaati peraturan yang berlaku. Jadi apabila ditinjau secara hukum maka perjanjian online sah karena memiliki dalam KUH Perdata khususnya pada Pasal 1320 dan 1338 KUH Perdata mengenai perjanjian. Adapun berkaitan dengan keabsahan bukti-bukti yang digunakan mengacu pada Undang-Undang Nomor 11 Tahun 2008 tentang ITE Pasal 5 tentang inforrnasi, dokumen dan tanda tangan elektronik. Terkait mekanisme dari pelaksanaan perjanjian pinjaman dan pihak-pihak yang terlibat diatur melalui Peraturan OJK Nomor 77/POJK/2016 tentang Layanan sebuah Pinjaman dalam bentuk Uang Berbasis sebuah Teknologi lnformasi.

\section{Perlindungan Hukum terhadap Kreditur yang Melakukan Penjanjian Pinjaman Online Berbasis Financial Technology (Fintech)}

Untuk menghindari terjadinya kerugian yang menimpa kedua belah pihak yang melaksanakan perjanjian pinjaman online berbasis Financial Technology (Firuech), maka diperlukan sebuah konsep perlindungan hukum terhadap kedua belah pihak yang melaksanakan perjanjian pinjaman. Konsep perlindungan pada bidang hukum dibagi menjadi 2 yaitu perlindungan hukum secara preventif yang bersifat mencegah dan perlindungan hukum represif yang bersifat memberikan efek jera.

Perlindungan hukum preventif dilaksanakan melalui perjanjian yang mencantumkan aturanaturan dan konsekuensi terhadap pelanggaran perjanjiannya. Dalam perjanjiannya terdapat sebuah dokumen yang secara elektronik, dokumen itu sendiri dirancang oleh seorang debitur atau pihak yang memberikan pinjaman yang isinya mengenai sebuah aturan serta sebuah kondisi yang diwajibkan untuk selalu dipatuhi oleh seorang kreditur. Akan tetapi dalam hal perjanjian tersebut tidak diperbolehkan memberatkan kreditur. Perlindungan hukum untuk seorang debitur terutama memberikan penekanan pada hal bayaran sebuah cicilan kredit. Debitur mewajibkan kreditur untuk melakukan pembayaran cicilan, dimana apabila terjadi keterlambatan pembayaran maka akan ada konsekuensinya. Pada umumnya konsekuensi dari keterlambatan tersebut yaitu pengenaan bunga yang besarannya diatur dalam perjanjian. Perlindungan hukum untuk kreditur terletak pada data seseorang secara pribadi dalam penggunanya di media elektronik yang seharusnya diberikan perlindungan secara hukum. Oleh karenanya untuk menjaga komitmen pihak yang menunaikan prestasi agar tidak ingkar janji, maka dibutuhkan suatu jaminan.

Jaminan dari perjanjian pinjaman pada umumnya memiliki nilai yang minimal sama berharganya dengan pinjaman yang diberikan oleh kreditur. Tujuan dari perjanjian antara debitur dan kreditur yaitu untuk mendapatkan suatu kepastian secara hukum. Meskipun demikian tidak jarang terjadi pelanggaran isi perjanjian yang dilakukan oeh debitur, seperti kemacetan pembayaran kredit sesuai perjanjian. Hal tersebut akan merugikan kreditur sebagai pemberi pinjaman. Jika terjadi wanprestasi dalam pelaksanaan perjanjian, maka pihak penyelenggara mengupayakan melakukan penagihan melalui kerjasama dengan jasa unit penagihan serta mengupayakan mediasi agar tidak terjadi wanprestasi oleh debirur. Kerugian yang timbul bisa terjadi diakibatkan oleh kekeliruan dari 
tindakan penyelenggara dalam menganalisis, menyeleksi dan menyetujui pinjaman. Maka sesuai dengan ketentuan Pasal 37 aturan OJK Norn or 77 /POJK .0I/2016 tentang layanan sebuah pinjaman dalam bentuk uang yang berbasis sebuah teknologi informasi menjelaskan bahwa apa bila keputusan dari penyelenggara merugikan kreditur maka penyelenggara dapat dikenakan sanksi yang diatur dalam ketentuan Pasal 47 aturan OJK Nomor 77/POJK.01/2016 tentang Layanan sebuah Pinjaman dalam bentuk uang yang berbasis sebuah Teknologi lnformasi. Adapun bentuk sanksi yang diberikan yaitu sanksi dalam bentuk administratif. Sanksi JO administratif yang dapat diberikan kepada penyelenggara yang merugikan kreditur sesuai dengan ketentuan Pasal 47 POJ K.

Berdasarkan hal tersebut maka perlindungan hukum terhadap kreditur dalam perjanjian Pinjaman Online Berbasis Financial Technology (Fintech) diatur dalam POJK Nomor 77 Tahun 2016. Perlindungan hukum kepada seorang kreditur tersebut pada hal ini yaitu apabila terjadi kerugian yang menimpa kreditur akibat kelalaian dari penyelenggara pinjaman atau wanprestasi yang dilakukan oleh debitur. Kedua sengketa tersebut bisa diselesaikan melalui dua jalur, yaitu melalui sebuah jalur pada bidang pengadilan yang secara urnumnya serta melalui jalur dari luar pengadilan dengan difasilitasi oleh Lembaga alternatif penyelesaian sengketa.

\section{SIMPULANDAN SARAN}

\section{Simpulan}

Dari hasil analisi data, dapat disimpulkan bahwa kedudukan hukum perjanjian Pinjaman Online Berbasis Financial Technology (Fintech) sah secara hukum karena memiliki landasan dalam KUH Perdata Pasal 1320 dan berkaitan dengan keabsahan bukti-bukti yang digunakan mengacu pada Undang-Undang Nomor 11 Tahun 2008 tentang Informasi dan Transaksi Elektronik (Undang-Undang ITE) Pasal 5 tentang informasi, dokumen dan tanda tangan elektronik. Terkait mekanisme dari pelaksanaan perjanjian pinjaman dan pihak-pihak yang terlibat diatur melalui Peraturan Otoritas Jasa Keuangan Nomor 77/POJK/2016 tentang Layanan Pinjam Meminjam Uang Berbasis Teknologi Informasi. Perlindungan hukum terdiri atas perlindungan hukum preventif yaitu debitur harus memberikan suatu jaminan demi menjaga kepercayaan kreditur dan perlindungan hukum represif digunakan ketika terjadi wanprestasi berupa perlawanan hukum yang dilakukan oleh pihak debitur kepada kreditur dalam suatu perjanjian kredit.

\section{Saran}

Dari hasil panelitian di atas, adapun yang menjadi saran yaitu kepada Pemerinta untuk mempertegas peraturan otoritas jasa keuangan dan KUH Perdata. Kepada masyarkata dan perusahaan Fintecn diharapkan agar melaksanakan kegiatan usaha dengan jujur dan beritikad baik serta dalam menjalankan usahanya wajib berpedoman dan tunduk sesuai dengan peraturan perundang-undangan yang berlaku untuk meminimalisir risiko dalam perjanjian pinjaman online.

\section{DAFTAR PUSTAKA}

Baihaqi, J. (2018). Financial Technology Peer-To-Peer Lending Berbasis Syariah di Indonesia. Journal of Sharia Economic Law, 1(2), 116-132.

Budiyanti. (2019). Upaya Mengatasi Bisnis Finansial Teknologi. Jurnal Info Singkat, 11(4), 20-31.

Fais, K. (2021). Perlindungan Hukum Bagi Pengguna Layanan Pinjam Meminjam Uang Berbasis Tegnologi Informasi. Jurnal Hukum, 13(1), 70-90.

Ghazali, D. S., \& Usman, R. (2012). Hukum Perbankan. Jakarta : Sinar Grafika.

Istiqamah. (2019a). Analisis Pinjaman Online oleh Fintech dalam Kajian Hukum Perdata. Jurusan Ilmu Hukum Fakultas Syariah Dan Hukum, 6(2), 291-306.

Istiqamah. (2019b). Analisis Pinjaman Online oleh Fintech Dalam Kajian Hukum Perdata Hukum Fakultas Syarian dan Hukum, 6 (2). Jurnal Jurisprudentie, 6(2), 291-306.

Noor, I. H. (2011). Pemanfaatan Ilmu Pengetahuan dan Teknologi dalam Kegiatan Pengabdian Masyarakat di Perguruan Tinggi. Jurnal Pendidikan Dan Kebudayaan, 17(3).

Novinna, V. (2020). Perlindungan Konsumen dari Penyebarluasan Data Pribadi oleh Pihak Ketiga. Jurnal Magister Hukum Udayana (Udayana Master Law Journal), 9(1), 92-110.

Sugangga, R., \& Sentoso, E. H. (2020). Perlindungan Hukum Terhadap Pengguna Pinjaman Online (Pinjol) Ilegal. Jurnal of Law, 1(1), 47-61.

Sugiyono. (2013). Metode Penelitian Pendidikan Pendekatan Kuantitatif dan Kualitatif. Alfabeta. 
Wahyuni, R. A. E., \& Turisno, B. E. (2019). Praktik Finansial Teknologi Ilegal dalam Bentuk Pinjaman Online Ditinjau dari Etika Bisnis. Jurnal Pembangunan Hukum Indonesia, 1(3), 379391.

Yuliana, O. Y. (2000). Penggunaan Teknologi Internet dalam Bisnis. Jurnal Akuntansi Dan Keuangan, 